\title{
Kerklike tradisie en kultuur as bydraende faktore in die diens aan die Koninkryk - die lewe en werk van dominee Kálmán Papp II (geb. 1924)
}

\begin{abstract}
Author:
Kálmán D. Papp ${ }^{1}$

Affiliation:

${ }^{1}$ Department of Dogmatics

and Christian Ethics,

University of Pretoria,

South Africa

Note:

This article is based on the PhD thesis of K.D. Papp, with the title: 'Die lewe en werk van ds. Kálmán Papp II (geb. 1924), met verwysing na die Hongaarse agtergrond, die Nederlandse periode en die Suid-Afrikaanse periode', the promotors were Dr Kobus Labuschagne and Prof J. Buitendag at the Department of Dogmatics and Christian Ethics (2010).
\end{abstract}

Correspondence to: Kálmán Papp

Email:

papp@biblesociety.co.za

Postal address:

11 Weaver Grove,

Farrarmere, Benoni 1501,

South Africa

\section{Dates:}

Received: 03 Oct. 2012

Accepted: 15 Feb. 2013

Published: 22 May 2013

How to cite this article: Papp, K.D., 2013, 'Kerklike tradisie en kultuur as

bydraende faktore in die diens aan die Koninkryk - die lewe en werk van dominee Kálmán Papp II (geb 1924)', HTS Teologiese Studies/ Theological Studies 69(1), Art. \#1339, 8 pages. http:// dx.doi.org/10.4102/hts. v69i1.1339

\section{Copyright:}

(C) 2013. The Authors. Licensee: AOSIS

OpenJournals. This work

is licensed under the

Creative Commons

Attribution License.

Read online:
Church tradition and culture as contributory factors in service to the Kingdom. This study describes how reverend Kálmán Papp (1924-) was able to leave his land of origin behind under difficult, unasked-for and compelling circumstances and embrace a new future in a far-off and unknown country. This follows from his spontaneous responding and acting positively to the effects of cultural interaction and the common denominational factor of the Reformed Church ever present. The study argues in its methodology that it is an oversimplification and a mistake to seek truth by avoiding, underestimating or eliminating the necessary outcome of cultural interaction and church tradition in the choices we make (even theologically) and experiences we have of life. This is the true life story of a church minister who finds his destiny and becomes himself a minister in the service of God's Kingdom, through faith's challenges and encounters with the theologies and cultures of his embracing worlds.

\section{Inleiding}

'n Hele aantal predikante, hoofsaaklik afkomstig vanuit Nederland, het gedurende die tweede helfte van die negentiende eeu en die eerste helfte van die twintigste eeu na Suid-Afrika gekom om predikante te word in die Nederduitsch Hervormde Kerk van Afrika (NHKA). Een van hulle, dominee Kálmán Papp (geb. 1924) - met predikante in sy familie vir sewe geslagte voor hom, en die Suid-Afrikaanse stamvader van die familie Papp - was egter nie uit 'n stamland van die Afrikanervolk afkomstig nie, maar van Hongarye -'n land waarmee Suid-Afrika en die kerke van Suid-Afrika ten tye van Papp se emigrasie na Suid-Afrika, weinig kontak gehad het.

Daar kan tereg gevra word hoekom Papp sy geboorteland verlaat het om in 'n ver land 'n nuwe toekoms te gaan soek, en in hoe verre die gemeenskaplike tussen die Hervormde Kerk in Hongarye en Suid-Afrika, asook 'n moontlike gemeenskaplikheid tussen die Hongaar en die Afrikaner, dit vir hom makliker gemaak het om in te skakel. Wat is die moontlikheid vir 'n predikant om met sukses volledig in 'n ander kerk opgeneem te word, en vir 'n Hongaar om 'n trotse Afrikaner te word en volledig deur sy mede-Afrikaners as volksgenoot aanvaar te word, in ' $n$ vreemde land met ' $n$ vreemde taal? Watter gemeenskaplikhede en raakpunte het hierin 'n rol gespeel in Papp se lewe? Daar kan inderdaad gevra word of kultuur in die goeie voortgang van die kerk en die teologie 'n belemmerende rol speel, of dalk ook vanuit kulturele interaksie' $n$ bevorderende rol kan speel?

Aangesien beide, Papp se vader en sy oudste seun dieselfde name dra as hy, word daar verder in hierdie artikel na hom verwys as Kálmán II. Na sy vader word verwys as Kálmán I en na sy seun as Kálmán III.

Die antwoorde op hierdie genoemde vrae sal ons in hierdie studie vind, sekerlik en veral, daarin dat Kálmán II regdeur sy lewe begelei word deur die gemeenskaplike van die een denominasie van die Hervormde Kerk (in Hongarye, in Nederland, in Suid-Afrika), maar daar is ook meer te vinde in die vorming van die breër kulturele interaksie waarin hy betrokke geraak het. Sy geloofservaring van die Heer en sy Kerk wat jou dra, en wêrelde van 'n breër kulturele interaksie wat jou vorm en geskik maak om selfs in onbekende (selfs ongevraagde) wêrelde in gehoorsaamheid koninkrykswerk te verrig, is aktueel en relevant om iets te leer vir elke predikant en Christen. Die relevansie van hierdie studie setel in die feit dat elkeen wat Koninkrykswerk verrig immers gekonfronteer word met uitdagings. Hierdie teologiese refleksie word aangebied in die vorm van ' $n$ narratief wat vertel van ' $n$ man wat sy geloofsweg ervaar het, gedra deur die grootsheid van die Heer en sy Kerk; teologiese vorming wat uit verskillende wêrelde tot hom kom; 'n breër kulturele-interaksie wat vanuit verskillende omgewings hom vorm en sy taak op hom lê; 'n taak wat hy dan van harte omhels in 'n lewe vir die plaaslike gemeente, maar ook vir die Kerk in ekumeniese verband, en ook vir die samelewing en nuwe assosiasies waarin 
hy homself gevind het. Dis 'n verhaal van aanhoudende toneelveranderings, krisisse, spanning, vlug vir jou lewe, uitdagings en hoogtepunte. Dis 'n verhaal wat sê wat dit moontlik maak dat dit gedoen kan word.

\section{Agtergrond Volk, land en taal}

Kálmán II se geboortevolk het 'n aangrypende en veelbewoë geskiedenis wat oor 'n periode van meer as duisend jaar strek en waarvan die wortels teruggevoer kan word tot by die stamverbond van die Ogoere, 'n Fins-Oegriese gemeenskap wat wes van die Oeralgebergtes in die verre ooste van Europa in die omgewing van die Wolga-, Kamaen Belajarivier gewoon het (vgl. Bucsay 1977:3-4). Ongeveer 500 n.C. het hierdie gemeenskap in twee verdeel:

This Finno-Ugrian community eventually split into the Finnish and Ugrian branches. Later the Ugrian branch divided into the present-day Ugrians of the Ob valley - the Voguls and Ostyaks - and into the ancestors of the Hungarians. (Pamlényi 1973:15)

Laasgenoemde groep het vanaf die middel van die sesde tot aan die begin van die negende eeu in die Kazareryk rondom die Kaspiese See gewoon en hulleself vrywillig onder die heerskappy van dié se vors, die Kaghan, gestel (vgl. Pamlényi 1973:17).

Rondom 870 het die Hongaarse Nyék-, Megyer-, Kürt-Gyarmat-, Tarján-, Jenö-, Kér- en Keszistam, verder weswaarts getrek en hulleself in die Karpatedal in Sentraal-Europa gaan vestig. Op die vooraand van hulle besetting van die Karpatedal, het die hoofde van die sewe stamme besluit om ' $n$ prins as hulle gemeenskaplike leier te kies. Die keuse het op Álmos, leier van die Magyare geval. Onder die leiding van sy seun Árpád, het die Hongare die Morawiese Slawiërs - wat in die noordelike deel van die Karpatedal gewoon het - aan hulle onderwerp, en die gebied wat later as Hongarye bekend sou staan, in 896 in besit geneem. Hierdie gebied het gestrek vanaf die Karpateberge in die noorde, die Transsilvaniese berge in die ooste en die Leitarivier in die weste tot op die grens van die groot laagvlakte, wat die bekken vorm van die Donau-, Tisza- (Theiss-) en Rába- (Raab-) rivier (vgl. Ignotus 1972:23). Prins Vajk, agter-agterkleinseun van Árpád, wat na sy bekering tot die Christendom die naam István (Stefanus) gekry en die Hongaarse stamme verenig het, is op 01 Januarie 1001 tot die eerste koning van die nuwe feodale Koninkryk van Hongarye gekroon (vgl. Pamlényi 1973:71).

$\mathrm{Na}$ die totstandkoming van die koningskap het Hongarye deur die loop van eeue talle winste en verliese van grondgebied beleef, maar telkens weer teruggekeer tot sy historiese grense. Hongarye se bondgenootskap met Oostenryk en Duitsland in die Eerste Wêreldoorlog het hom egter duur te staan gekom. Hongarye was verplig om 232000 vierkante kilometer van sy grondgebied aan omliggende lande af te staan. Sekere gebiede is tydens die aanloop tot die Tweede Wêreldoorlog met die hulp van Duitsland weer teruggewen, maar direk na afloop daarvan weer verloor. Die land beslaan tans 93030 vierkante kilometer en grens aan die Ukraïne in die noord-ooste, Roemenië in die ooste en suid-ooste, Serwië in die suide, Kroasië in die suidweste, Oostenryk in die weste en Slowakye in die noorde (vgl. Halász 1963:9).

Die bevolking van Hongarye het met die Vredesverdrag van Trianon (04 Junie 1920) vanaf bykans 21000000 afgeneem tot net meer as 7600000 (vgl. Milotay 1929:39-40). Volgens die 1994-sensus het die bevolking 10600000 getel en daar word geraam dat daar vandag ongeveer 3000000 Hongare buite die landsgrense van Hongarye woon (vgl. Tóth 1995:44). Volgens dieselfde sensus behoort bykans 93\% van die bevolking aan een van die drie historiese kerke: die Rooms-Katolieke Kerk (67.8\%), Hervormde Kerk (21\%) en Evangelies-Lutherse Kerk (4\%) (vgl. Tóth 1995:49).

Die Hongaarse taal behoort tot die Oegriese tak van die FinsOegriese oertaal wat deel was van die Oeralse taalfamilie. Slegs vyf moderne tale, dié van die Vogul- en Ostiakstamme van Siberië, Fins, Estonies en Turks, kan met Hongaars verbind word (vgl. Berlitz 1983:20). Hongaars word vandag deur geen ander taalgroep verstaan nie (vgl. Ignotus 1972:21).

\section{Kerk}

Die kerkhervorming het vroeg en vinnig op Hongaarse bodem grondgevat. Omdat Duits in daardie stadium die lingua franca was, is Martin Luther (1483-1546) se leerstellings nie net vanaf die kansels verkondig nie maar ook wyd en syd gelees. In 1522 skryf die eerste studente vanuit Hongarye aan die Universiteit van Wittenberg in om onder Luther en Melanchton (1497-1560) te studeer. Die meeste het na afloop van hulle studies na hulle vaderland teruggekeer en die Protestantse leer met groot ywer verkondig (vgl. Szabó 1927:7).

Die grootste invloed op die kerkhervorming in Hongarye is egter deur Heinrich Bullinger (1504-1575) uitgeoefen, veral as gevolg van sy jarelange verbintenis met die Hongaarse volk en kerk (vgl. Zsindely 1967:57). Die Protestante in Hongarye het hulle gevolglik al hoe meer aan die kant van die Switserse Hervormers geskaar. Die Sinode van Gönc aanvaar in 1566 'n belydenis van Béza asook Bullinger se Confessio Helvetica Posterior (vgl. Papp 1999:9) wat 'n jaar vantevore geskryf is. Op 22 Augustus 1567 aanvaar die Sinode van Debrecen die Confessio Helvetica Posterior tesame met die Heidelbergse Kategismus as belydenisskrifte van dié kerk (vgl. Tóth 1995:48). Hierdie datum word vandag beskou as die geboortedag van die Hervormde Kerk van Hongarye (vgl. Révész 1956:33).

Aan die begin van die negentiende eeu het die nasionalistiese strewes oral in Europa skielik begin toeneem en met die uitbreek van die vryheidsoorlog teen die Habsburgers op 15 Maart 1848, het die Protestantse kerke hulle heelhartig met die vryheidstrewe van die volk vereenselwig (vgl. Bucsay 1979:65). Dit het inderdaad daartoe gelei dat die Hervormde Kerk, as die grootste Protestantse denominasie in Hongarye, met verloop van tyd die kerk vir die volk én kerk van die volk geword het. 
Volgens die publikasie Egyházunk: A Magyarországi Református Egyház [Ons Kerk: Die Hervormde Kerk van Hongarye], sien die struktuur van die kerk netso daar uit as dié van die meeste ander reformatoriese kerke: die egyházközségek [plaaslike gemeentes, letterlik kerkgemeenskappe] word georganiseer in egyházmegyének [ringe, letterlik kerkprovinsies], die verskillende ringe vorm saam 'n egyházkerület [distrik, letterlik kerkstreek] en die distrikte vorm saam die Zsinat [sinode].

Die Heidelbergse kategismus is in sy Latynse vorm in 1566 in Hongarye gedruk en die eerste Hongaarse vertaling daarvan verskyn in 1577 in Pápa (vgl. Hervormde Kerk van Hongarye 1965:13). Tussen 1619 en 1646 is dit deur verskeie distriksvergaderings aanvaar as kategesehandleiding en belydenisskrif (vgl. Nagy 1965:28-29). Die Apostolicum is sy enigste ekumeniese credo (vgl. Hervormde Kerk van Hongarye 1997:35).

Die opleiding van predikante vir die Hervormde Kerk van Hongarye het sedert die vroegste tye aan die Hervormde Teologiese Akademies van die kerk se kolleges en universiteite plaasgevind. Voornemende predikante word vir ses jaar opgelei, waarvan vyf jaar aan 'n teologiese akademie deurgebring moet word. Die dissiplines waarin die studente onderrig word, kom ooreen met dié van die meeste reformatoriese kerke. Na afloop van die akademiese opleiding word 'n hulppredikerseksamen afgelê. Daarna moet die student vir minstens ' $n$ jaar in 'n gemeente praktiese opleiding onder die plaaslike predikant deurloop, waarna daar vir die predikerseksamen aangemeld kan word met die oog op beroepbaarstelling in die kerk (vgl. Hervormde Kerk van Hongarye 1994:362). Die ampspligte van die predikant kom grotendeels ooreen met dié van die meeste ander reformatoriese kerke. Dit was die agtergrond van Kálmán II se teologiese vorming in Hongarye waarmee hy Hongarye later sou verlaat vir nuwe onbekende wêrelde.

Die Hervormde Kerk van Hongarye handhaaf sedert die vroegste tye omvangryke ekumeniese betrekkinge met reformatoriese kerke in Switserland, Nederland, Duitsland, Skotland en die Verenigde State van Amerika. Die Hervormde Kerk van Hongarye het reeds in 1909 aangesluit by die World Alliance of Reformed Churches (WARC), is sedert 1948 lid van die Wêreldraad van Kerke en sedert 1990 lid van die Internasionale Raad van Christene en Jode. Dit is 'n aktiewe lid van die Ekumeniese Raad van Kerke van Hongarye en werk onder andere met die Rooms-Katolieke Kerk saam aan 'n nuwe Hongaarse Bybelvertaling onder toesig van die Bybelgenootskap van Hongarye (vgl. Hervormde Kerk van Hongarye 1997:78).

Vanaf dominee István Bogdányi, 'n oor-oor-oor-oor-oorgrootvader van Kálmán II, was daar sonder 'n enkele onderbreking in elke geslagslyn van die voorgeslag van Kálmán II aan moederskant een of meer predikante (vgl. Papp 2010:114).

\section{Studentejare}

Toe die Tweede Wêreldoorlog amptelik op 22 Junie 1941 tussen Duitsland en Rusland uitbreek, het Hongarye onmiddellik tot die oorlog toegetree en op 26 Junie 1941 oorlog teen Rusland verklaar (vgl. Pamlényi 1973:517). Kálmán II matrikuleer 'n jaar later met Hongaars, Geskiedenis, Latyn, Duits, Natuurwetenskap en Wiskunde as hoofvakke en Dogmatiek en Etiek, Aardrykskunde en Volkekunde, Engels, Filosofie, Biologie en Uitvoerende Kuns as byvakke.

Na afloop van die somervakansie van 1942 vertrek Kálmán II na Debrecen vir tersiêre opleiding aan die Graaf Tissza István Universiteit van Debrecen wat sy oorsprong gehad het in die Collegium van Debrecen wat aanvanklik slegs predikante en onderwysers opgelei het. Die Collegium van Debrecen bestaan reeds sedert 1538 en is selfs ouer as die Universiteit van Utrecht in Nederland. Dit het later uitgebrei tot ' $n$ volwaardige universiteit. Die Universiteit het egter sy Hervormde karakter behou (vgl. Szekeres 1958:54).

Kálmán II se leermeesters te Debrecen was professore Kálmán Kállay (Ou Testamentiese Wetenskap), Károly Erdös (Nuwe Testamentiese Wetenskap), Laszló Pákozdy (Godsdiens- en Sendingwetenskap), Zsigmond Varga (Godsdiensgeskiedenis), István Török en Béla Vasady (Sistematiese Teologie), Sándor Makkai (Praktiese Teolgie), Béla Soós (Kerkgeskiedenis), Béla Szentpéteri Kun (Kerkreg) en Béla Tankó (Psigologie, Filisofie en Pedagogiek).

Kálmán II was nog nie afgestudeer toe die Russiese troepe die Hongaarse grens in Augustus 1944 oorgesteek het nie. Die meeste Hongare wat gevlug het, het agter die retirerende Duitse troepe aan na die weste gevlug. Kálmán II se moeder en suster het egter nie landuit gevlug nie. Hulle het êrens op die platteland gaan woon omdat dit daar veiliger was as in die stede wat voortdurend gebombardeer is. Toe die professore later ook begin vlug het, kon daar nie met lesings voortgegaan word nie en die universiteit moes noodgedwonge in die herfs van 1945 sluit. Kálmán II is toe terug na Miskolc waar hy met sy broer Zoltán en sy voormalige skoolvriend Gyula Kolláth en dié se familie kontak gemaak het. Gyula se vader, 'n skoolhoof, het besluit om saam met sy twee seuns, Gyula en Zoltán en sy dogter, Erzsébet in die bosse van die Bükkberge, ongeveer 50 kilometer van Miskolc af, te gaan skuiling soek totdat die vegtende troepe verby is. Kálmán II en sy broer Zoltán het besluit om met hulle saam te gaan en hulle het in Oktober 1945 met 'n perdekar vol voorrade, wapens en ammunisie vertrek.

Die Kolláths, Kálmán II en Zoltán het hulle tuisgemaak in 'n klein buitegeboutjie naby 'n jagtershut wat aan die adellike Oostenryks-Hongaarse Koburgh familie behoort het. Toe berig ontvang is dat die laerskole in Miskolc weer met onderrig begin het, het Kolláth besluit om saam met Zoltán en Erzsébet terug te gaan na Miskolc om sy werk te hervat en te gaan vasstel of die familie die oorlog oorleef het. Kálmán II se broer Zoltán het met hulle saamgegaan, maar hyself en Gyula het in die berge agtergebly, omdat die universiteite nog 
gesluit was. Kort daarna het vier Russe een nag onverwags by die jagtershut opgedaag en met hulle gewere teen die deur gestamp. Nadat die deur vir hulle oopgemaak is, het drie van hulle ingekom. Daar kon egter nie met hulle gekommunikeer word nie, aangesien hulle nie Hongaars, en Kálmán II en Gyula nie Russies magtig was nie. Gevolglik kon die intensie van die Russe se besoek nie bepaal word nie. Omdat hulle egter aggressief geword het, het Kálmán II en Gyula, net nadat ' $n$ vierde soldaat die huis betree het, elkeen twee van die Russe met pistole - wat Kálmán II en Gyula permanent by hulle gedra het - doodgeskiet. Hulle kon dit onder die omstandighede net nie waag om enige risiko's te loop nie (vgl. klankbandopnames van Kálmán II in NHKA, Argiefbewaarplek K2 5/4 Deel 3).

Kort na hierdie gebeure het Kálmán II verneem dat die teologiese opleiding in Debrecen weer hervat het en hy is in Augustus 1946 terug daarheen om met sy studie voort te gaan, na 'n verblyf van agt maande in die berge.

Aangesien Kálmán II eerder 'n akademiese loopbaan wou volg as om gemeentepredikant te word en omdat daar nie 'n gemeente was wat op hom gewag het nie, het hy besluit om 'n aanbod van 'n nagraadse beurs van die Rijksuniversiteit van Utrecht, die Stipendium Bernardinum, met dankbaarheid te aanvaar. Dit was vir hom 'n groot eer om deur sy leermeester, professor Kálmán Kállay, vir hierdie beurs aanbeveel te word en hy het die geleentheid met albei hande aangegryp. Die beurs was vir 'n termyn van drie jaar en vier van sy studentekollegas, János Kerekes, Ernö Kuhinka, István Tüski en Sándor Varga, het dit ook ontvang. Dit sou vir Kálmán II ook veel veiliger wees om in hierdie stadium liewer die land te verlaat, met die kommunistiese invloed wat vinnig in die land aan die orde gekom het.

Professor László Pap was verantwoordelik vir alle reëlings rondom die studente se reisdokumente en -uitgawes. Toe die regering ook op hom druk begin uitoefen het oor allerhande kerklike en politieke aangeleenthede, het Pap die reëlings rondom die studente se vertrek na Nederland bespoedig, ten spyte van die feit dat hulle nog een termyn van hulle kursus moes voltooi. Hulle sou aanvanklik per spoor reis, maar toe die druk op hom onhoudbaar begin word het, het hy uit vrees dat hy binnekort nie meer daartoe in staat sou wees om hulle te help nie, hulle laat weet dat hulle per vliegtuig via Praag na Amsterdam sou vlieg. Kálmán II en sy kollegas is toe op 19 Januarie 1947 landuit sonder dat hulle eers die geleentheid gehad het om hulle geliefdes te groet. Hulle kon nie hulle kursus voltooi, hulle proponentseksamen aflê, of hulle praktiese jaar in 'n gemeente doen nie. In Praag moes hulle twee nagte oorbly in afwagting op 'n aansluitingsvlug. Op 21 Januarie vertrek hulle vanuit Tsjeggo-Slowakye na Nederland (vgl. paspoort van Kálmán II in NHKA, Argiefbewaarplek K2 5/4 Deel 3).

Kort ná hulle vertrek het Kálmán II se vriend, Gyula Kolláth, wat saam met hom in die Bükkberge was, in die moeilikheid beland. Niemand weet presies wat hy gedoen het nie, maar daar word vermoed dat hy by anti-regeringsaksies betrokke geraak het. Terwyl hy 'n voortvlugtige was, het hy op die polisie geskiet. Hy is kort daarna in hegtenis geneem en summier opgehang. Die blote besit van 'n vuurwapen het in daardie tyd reeds die doodstraf regverdig. Gyula se suster Erzsébet het Kálmán II per brief in Nederland in kennis gestel van hierdie tragiese gebeure en dit het hom diep getref.

Daar word afgelei dat Gyula vir sy vader vertel het dat hy en Kálmán II die vier Russe in die berge om die lewe gebring het. Verder word daar ook vermoed dat Gyula se vader dit, waarskynlik om te kompenseer vir die feit dat sy seun deur die Kommuniste opgehang is, met 'n redelike mate van trots oorvertel het. Nadat die voorval van Kálmán II, Gyula en die vier Russe onder die aandag van die owerhede gekom het, is daar met ' $n$ amptelike ondersoek begin. Na aanleiding daarvan is Kálmán II se broer Zoltán, die bosbewaarder en die Kolláths gevange geneem en in die tronk gestop. Zoltán was vyf maande in die tronk en dit het hom amper sy lewe gekos, aangesien hy daar onder andere met tuberkulose besmet geraak het (vgl. klankbandopnames van Kálmán II in NHK Argiefbewaarplek K2 5/4 Deel 3).

\section{Verblyf in Nederland}

Kálmán II en sy kollegas is op 21 Januarie 1947 in Amsterdam deur professor J. Severijn van die Rijksuniversiteit van Utrecht en voorsitter van die Stigting Stipendium Bernardinum ontvang en na Utrecht geneem (vgl. paspoort van Kálmán II in NHKA Argiefbewaarplek K2 5/4 Deel 3). Volgens 'n inskrywing in sy paspoort, word Kálmán II op 23 Januarie 1947 by die Gemeente Politie te Utrecht as vreemdeling in Nederland geregistreer (vgl. NHKA Argiefbewaarplek K2 5/4 Deel 3). Severijn het vir die Hongare huisvesting gereël by gesinne wat slegs Nederlands magtig was. Die doel van die plasing was dat die Hongaarse studente gedwing sou word om die Nederlandse taal so gou as moontlik aan te leer.

Die teologiese toneel in die Nederlandse Hervormde Kerk is gedurende die jare van Kálmán II se verblyf in Nederland ongetwyfeld die meeste deur die teologie van Karl Barth beïnvloed. Een van Barth se belangrikste volgelinge was juis die Nederlander Kornelis Heiko Miskotte (1894-1976), hoogleraar in Dogmatiek en Bybelse Teologie in Leiden vanaf 1945 tot 1959 (vgl. Van de Beek 2006:126). Th.L. Haitjema stel in 1926 reeds 'dat Karl Barth een beteekenisvolle boodschap heeft aan ons, Nederlandsche Theologen', en '[i]k mag niet anders dan trachten, de Nederlandsche theologen bereid te maken, naar Karl Barth's getuigenis met aandacht te luisteren' (Haitjema 1926:137-138). Barth se invloed was natuurlik reeds in Hongarye sigbaar en Kálmán II het nou weer daarmee in aanraking gekom. Hy sou sy lewe lank in sy prediking telkens die teologiese invloed van Barth weerspieël.

Ten spyte van die feit dat die Hongaarse studente nie hulle opleiding in Hongarye voltooi het nie, is hulle toegelaat om aan die Rijksuniversiteit van Utrecht vir doktorale studie in te skryf. Die eerste studiejaar is hoofsaaklik gebruik om Nederlands aan te leer sodat hulle die lesings kon volg en 
aan teologiese gesprekke kon deelneem. Vanaf die eerste Sondag het hulle ook eredienste bygewoon waar hulle die Skriflesing en liedere in die Nederlandse Bybel en Liedboek gevolg het.

Kálmán II het Godsdienswetenskap as hoofvak gekies sowel as Ou Testamentiese Wetenskap, Arabies en Egipties, laasgenoemde twee in die Fakulteit Lettere, as byvakke. Professor H.W. Obbink, seun van die bekende orientalis professor H.Th. Obbink, het Godsdienswetenskap, Arabies én Egipties gedoseer. Kálmán II het aan die einde van 1947 namens die Hongaarse studente, wat met verloop van baie jare deur die tussengang van H.Th. Obbink, ontvangers van die Stipendium Bernardinum geword het, by dié se begrafnis opgetree (H.W. Obbink was vanaf 1951 tot 1961 redaksielid van die Hervormde Teologiese Studies).

Gedurende sy studentetyd het Kálmán II met 'n jong damestudent, Wilhelmina (Mieke) Schilling, in die studentekafeteria van die universiteit kennis gemaak. Sy was die jongste van vier dogters van wyle Diederik Hendrik Schilling, 'n afgetrede offisier van die Nederlandse Weermag, en Louise Clasina Nellie Porrey van Arnhem. Hulle het dadelik tot mekaar aangetrokke gevoel en met 'n verhouding begin wat later op hulle huwelik sou uitloop waaruit vier kinders, waarvan twee predikante geword het, gebore is.

\section{Vertrek na Suid-Afrika}

Aan die begin van 1948 het die Kommunistiese Party met behulp van die Russe daarin geslaag om die bewind in Hongarye oor te neem nadat hulle die leiers van die ander partye geëlimineer het, deur hulle na Rusland weg te voer. Kort daarna het die Hongaarse regering Kálmán II se uitlewering van die Nederlandse regering op grond van beweerde moorde wat hy sou gepleeg het, gevra. Hy het vir die eerste keer daarvan verneem in 'n uitknipsel uit 'n Hongaarse koerant wat die familie met 'n ompad aan hom gestuur het. Hy het toe besef dat die gebeure in die Bükkberge uitgelek het.

Kálmán II het die hele aangeleentheid toe met professor Severijn, wat ook voorsitter van die kuratorium was, gaan bespreek en hom vertel van alles wat tydens die oorlog in die Bükkberge gebeur het. Die professor, wat lid van die anti-Rewolusionêre Party van Nederland was, was nogal beïndruk met hom en het hom gerusgestel en gesê dat hy alles aan hom kan oorlaat. Hy het toe vir Kálmán II 'n afspraak gemaak met die Nederlandse Minister van Justisie, mnr Donner, wat hom die versekering gegee het dat hulle hom nie sal uitlewer nie (vgl. klankbandopnames van Kálmán II in NHKA Argiefbewaarplek K2 5/4 Deel 3).

'n Tweede uitleweringsversoek het die Nederlandse regering kort daarna bereik en hulle posisie het al hoe ongemakliker begin word. Indien hulle hom nie aan Hongarye sou uitlewer nie, sou die Russiese regering waarskynlik sy uitlewering op grond van beweerde oorlogsmisdade vra. So 'n versoek sou moeilik geweier kon word. Kálmán II het dus vir
Nederland 'n verleentheid begin word en hulle het besluit om met hom te onderhandel oor sy toekoms en aanbeveel dat hy dit moet oorweeg om na Amerika of Suid-Afrika te emigreer. Sy keuse het op Suid-Afrika geval, waar die taal en kultuur, asook die kerklike tradisie, baie nader aan dié van Nederland en Hongarye is. Dit was ook bekend dat daar in daardie stadium 'n groot tekort aan predikante in Suid-Afrika bestaan het. Bowendien was die Kommunistiese Party in Suid-Afrika 'n verbode party. Suid-Afrika het ook nie 'n uitleweringsooreenkoms met Hongarye gehad nie, met die gevolg dat hy daar beslis veiliger sou wees. Nadat die pogings van die Hongaarse regering misluk het om Kálmán II uitgelewer te kry, is hy in absentia deur die Volksgeregshof van Miskolc verhoor en op 06 November 1948 op grond van oorlogsmisdade ter dood veroordeel (vgl. NHKA Argiefbewaarplek K2 5/4 Deel 3). Kálmán II en Mieke het intussen besluit om te trou nadat hy hom in SuidAfrika sou vestig en die nodige sekuriteit kon bied.

$\mathrm{Na}$ alle waarskynlikheid was dit professor Severijn wat die Nederlandse Hervormde Kerk genader het met die versoek dat dié kerk by die NHKA navraag sou doen oor die moontlike akkommodering van Kálmán II. Dringende en spoedeisende korrespondensie van etlike maande het uiteindelik daartoe gelei dat die NHKA aangebied het om Kálmán II te huisves.

Daar is ooreengekom dat Kálmán II Nederland sou verlaat sonder om 'n adres agter te laat. Hy sou skielik net spoorloos verdwyn. Die regering het 'n vreemdelingepaspoort aan hom uitgereik en daar is gereël dat sy naam nie op die passasierslys van die vliegtuig sou verskyn nie. Hy het op 03 Oktober 1949 met die Nederlandse KLM lugredery oor Tunisië, Kano en Leopoldville na Johannesburg gevlieg - 'n vlug van sewe-en-twintig ure.

\section{Teologiese vorming in Suid-Afrika}

Kálmán II land op 04 Oktober 1949 te Palmietfontein, die destydse internasionale lughawe by Germiston. Professor doktor S.P. Engelbrecht, dekaan van die Fakulteit Teologie (Afdeling A) aan die Universiteit Pretoria, het homself as voog oor Kálmán II aangestel. Hy het vir hom 'n kamer gereël by 'n weduwee Uys te Brookstraat 130, Brooklyn, en gereël dat hy by die manskoshuis van die kerk, Voortrekker Tehuis, sy etes kon geniet.

Op 20 Oktober 1949 word Kálmán II verwelkom in 'n vergadering van die Kommissie van die Algemene Kerkvergadering om, soos die notule dit stel '... sy dank te betuig aan die Alg.Kom. vir die aandeel wat die Kom. gehad het om sy koms na S.A. moontlik te maak.' Hierdie besoek het waarskynlik ook 'n kennismaking met die Kommissie, aan wie hy tot op daardie stadium nog onbekend was, ten doel gehad (vgl. NHKA Argiefbewaarplek K1/1 1/1/8).

Aangesien die akademiese jaar reeds aan sy einde was het Kálmán II eers aan die begin van 1950 by die Universiteit van 
Pretoria ingeskryf. Hy het dadelik by die gemeente Pretoria ingeskakel en die vakansietyd benut deur soveel moontlik mense te leer ken. Uit die aard van die saak het hy eerste aansluiting by die Nederlanders gevind en goed bekend geraak met finalejaarstudent H.M.J. Kramer, wat ook in Nederland studeer het; die gesin Spruyt, latere skoonouers van dominee C.J. Labuschagne; die gesin Pont, ouers van proponent A.D. Pont en die gesin Bruins, by wie Mieke later ingewoon het. Hierbenewens het hy gereeld by professore S.P. Engelbrecht, B. Gemser, A.S. Geyser en A. van Selms en hulle gesinne aan huis gekom.

Die teologiese beeld van die Nederduitsch Hervormde Kerk en die opleiding van die Kerk aan die Universiteit van Pretoria in die jare wat gevolg het op die Tweede Wêreldoorlog - toe Kálmán II na Suid-Afrika gekom het en daarmee in aanraking gekom het - was soos dié van enige kerk en opleiding nie eenduidig nie. Tog kan sekere aanduidings waargeneem word. Die Hervormde Kerk het nooit volledig na een of ander uiterste beweeg nie, en het dus in die algemeen geneem afwysend gestaan teenoor sowel die liberale en modernistiese invloede aan die een uiterste, en die ortodoks-piëtisties invloede aan die ander uiterste. Hierdie gebalanseerde benadering het inderdaad 'n lang pad in die Hervormde Kerk gekom. Reeds dominee M.J. Goddefroy (1848-1920) het gewaarsku: 'Geen kerk zonder belijdenis' enersyds, maar ook andersyds '... geen belijdenisschrift of formulier boven of nevens het onbedrieglijke Woord des Heeren' (Breytenbach 1999:174). Teoloë in die Hervormde Kerk wat kennis geneem het van die resultate van die historiese kritiek, het in die Nederlandse etiese teologie of in die dialektiese teologie van veral Karl Barth hulle antwoorde gevind, om daarmee te sê dat die waarheid oor God nie 'n menslik-subjektiewe en rasioneel-bepaalde waarheid in die modernistiese sin of in die sin van die liberale teologie is nie, maar 'n geloofswaarheid vanuit die ontmoeting met God in Jesus Christus (vgl. Breytenbach 1999:173-176). Dit was veral B. Gemser, professor in Ou Testamentiese Wetenskap (vanaf 1926 tot 1955), wat vanuit die oriëntasie van die Nederlandse etiese teologie die historiese kritiek beoordeel het (Breytenbach 1999:174). C.H. Rautenbach, wat indringend ingegaan het op die wortels van die etiese teologie in die opleiding van B. Gemser, J.H.J.A. Greyvenstein en S.P. Engelbrecht, kom tot die gevolgtrekking dat die hoofstroming in die opleiding aan die Universiteit van Pretoria nogtans meer in lyn met Hoedemaker se Konfessionele Rigting was (Van Wyk 1999:190, 191). Verder was dit veral H.P. Wolmarans, professor in Godsdiens en Sendingwetenskap (vanaf 1934 tot 1959), wat die dialektiese teologie van Barth in die Hervormde Kerk en opleiding bekend gestel het (vgl. Breytenbach 1999:174, 175).

Kálmán II het deurgaans, met sy teologiese agtergrond vanuit die Hervormde opleidings in Hongarye, Nederland en nou ook Suid-Afrika, getoon dat hy eweneens beslis die twee uiterstes wou vermy van enersyds liberale en modernistiese invloede en andersyds ortodoks-piëtisties invloede. Sy lewe lank sou die teologiese invloed van veral Karl Barth by hom deurskemer. Daar is egter in beide Barth se teologie en in die etiese teologie reeds tekens van 'n post-fondamentalistiese teologie wat teruggedeins het van enige finale woord by die mens of 'n gearriveerde leerstelligheid. Waar dit miskien nie duidelik by Kálmán II deurskemer nie, is daar by hom nietemin ook steeds die ingesteldheid teenwoordig van die basiese insigte van die Reformatoriese teologie soos dit in die algemeen deur predikante in Suid-Afrika verstaan is. In Suid-Afrika het Kálmán II groot bewondering vir Gemser en veral Van Selms gehad, vir hulle buitengewone intellek en vir die besondere mense wat hulle was.

Ná die Desembervakansie het Kálmán II aan die einde van Januarie 1950 aan die Universiteit van Pretoria ingeskryf as doktorale student in Godsdienswetenskap met professor H.P. Wolmarans as studieleier. Kálmán II wou in Godsdiensgeskiedenis spesialiseer met die klem op die Islam en Egiptiese godsdienste. Vir hierdie doel sou hy onder leiding van professor A. van Selms ook Arabies en Egipties bestudeer. Professor S.P. Engelbrecht het Kálmán II ook versoek om die finalejaarstudente se lesings in Dogmatiek en Kerkgeskiedenis by te woon. Sy medestudente was J.I. de Wet, J.M. Labuschagne, J.P. Oberholzer, B.J. van der Merwe, C.J. van Schalkwyk en J.A. Viljoen (vgl. NHKA 1951:137).

$\mathrm{Na}$ 'n paar maande se studie het Kálmán II besluit om aansoek te doen om toelating tot die proponentseksamen sodat hy preekondervinding kon opdoen en van nader met die kerklike lewe in die praktyk kennis kon maak. Die proponentseksamen is egter eers in April 1951 afgeneem nadat Kálmán II sy proefpreek op Sondag 04 Februarie 1951 in die kerkgebou van die gemeente Pretoria gehou het. Nadat hy gedurende Maart en April vier eredienste in die gemeente Kaapstad waargeneem het, het hy vanaf Mei tot Julie afloswerk in die gemeente Potchefstroom gedoen. Dit is onderbreek deur Kálmán II en Mieke se huweliksbevestiging. Op Saterdag 02 Junie 1951 word hulle deur professor B. Gemser in die kerkgebou van die gemeente Pretoria in die huwelik bevestig. Vanaf Augustus tot Oktober 1951 het Kálmán II in die gemeente Witbank, wat in daardie stadium vakant was, uitgehelp.

Kálmán II sou sy roeping as predikant in 'n verre en onbekende land vervul. Dinge wat hy nie in sy jeugjare kon voorsien nie, was lankal aan die gebeur. Afgesien van die beskerming van die Hoër Hand wat hy as gelowige deurgaans ervaar het, was daar ook, menslik gesproke, sigbare faktore wat besig was om uit te kristaliseer. Die mensehande wat na hom uitgereik het, en sekerlik daartoe gelei is (gesien deur die oog van die geloof), was veral dit wat tot uitdrukking gekom het deur die kerklike denominasie wat altyd dieselfde gebly het en hom met soveel liefde en verantwoordelikheid ondersteun het. Daar was egter ook die uitwerking van die kulturele interaksie tussen Nederland en Suid-Afrika, wat nie geringskat moet word nie, omdat dit hom juis gehelp vorm en voorberei het vir die taak waaraan hy sy lewe sou wy.

\section{Bedieningstyd as predikant}

Op 22 September 1951 word Kálmán II na die gemeente Krugersdorp beroep as medeleraar vir dominee W.F.H. 
Huyzers. Hy is op Saterdag 03 November 1951 deur professor S.P. Engelbrecht georden en bevestig, en het op Sondag 04 November sy intreepreek gelewer. Hiermee het sy ononderbroke dienstermyn van veertig jaar in die gemeente begin - tot dusver die enigste predikant van die Nederduitsch Hervormde Kerk van Afrika wat al veertig sy diensjare in sy eerste en enigste gemeente voltooi het. Hoewel hy verskeie beroepe ontvang het, het hy nooit ' $n$ ander beroep aanvaar nie.

Die kulturele interaksie word spoedig sigbaar. Kálmán II en Mieke het gedurende Desember 1951 hulle eerste Geloftefees te Paardekraal bygewoon. Hulle het daarna elke jaar getrou die vroeë oggenderediens om 05:00 op 01 Desember te Pretoriuskraal asook die feesvieringe gedurende die week van 16 Desember te Paardekraal bygewoon en Kálmán II het in 1952 die erediens gelei. Hy sou ook later lid en voorsitter van die Geloftefeeskomitee word en selfs as hoofspreker by die fees optree (vgl. Papp 1951-1979:5). Kerk en kultuur speel hulle vormende rol, rus hom toe, en laat deure vir hom oopgaan, sodat hy sy rol as bedienaar van die Evangelie in die kerk en samelewing kan vervul. Omdat hy as predikant aanvaar is, is Kálmán II eventueel ook as kultuurleier aanvaar. Hy het homself, in teenstelling met baie ander immigrante, van die begin af volledig met die lotgevalle van die Afrikaner vereenselwig en homself met hart en siel in dié volk se wel en wee ingegrawe. Gou het hy homself met die geskiedenis van die Afrikaner vertroud gemaak en baie navorsing daaroor gedoen, veral oor die gelofte van Paardekraal. Oor die oorsprong van hierdie gelofte het hy later 'n insiggewende artikel vir die tydskrif HTS Teologiese Studies geskryf (vgl. Papp 1995:189-206). Hy was sy lewe lank baie trots daarop dat hy vir menige Afrikaner iets oor hulle eie geskiedenis kon leer. Vir sy bydraes op die gebied van die godsdiens, kultuur en onderwys binne die gemeenskap van Krugersdorp, het hy later 'n sertifikaat van verdienste van die Stadsraad van Krugersdorp ontvang.

Op Kersdag 1951, na afloop van die oggenddiens wat destyds om 05:00 in Krugersdorp gehou is, het Kálmán II vir die eerste keer nagmaal aan die Hongaarse gemeenskap van die Witwatersrand in die kerkgebou van die gemeente Johannesburg bedien. Hy het met die Hongaarse eredienste, aanvanklik in die kerkgebou van die gemeente Johannesburg, daarna in dié van die Nederlandssprekende gemeente in Johannesburg, en later weer in dié van die gemeente Johannesburg, volgehou, selfs vir jare ná sy emeritaatsaanvaarding in 1991. Die Hongaarse Hervormers is as ' $n$ wyk van die gemeente Krugersdorp onderhou. Nagmaal is gereeld bedien, veral op kerklike feesdae soos dit die gebruik in Hongarye was, en so ook die doop van enkele kinders, meestal in die kerkgebou van die gemeente Krugersdorp. Daar is geen kategetiese onderrig gegee of belydenis van geloof afgeneem nie aangesien die meeste kinders in Engelse skole beland en in die Engelse gemeenskap en kerke opgeneem is. Kálmán II het egter wel 'n aantal Hongaarse huwelike bevestig en begrafnisdienste gelei. Meer as dít kon hy, as gevolg van 'n gebrek aan tyd, nie doen nie. Tydens die hulpverlening aan die Hongare wat na aanleiding van die Hongaarse Rewolusie van 1956 na Suid-Afrika gevlug het, was hy swaar belas met talle bykomende verantwoordelikhede. Hy het van meet af aan alles in sy vermoë gedoen om die Hongare by te staan en geen moeite ontsien om hulle gevestig te kry nie. Vir sy intensiewe betrokkenheid oor die jare heen het hy later ' $n$ spesiale medalje van die Hongaarse regering ontvang asook 'n ereprofessoraat van die Teologiese Akademie van die Hervormde Kollegium van Sárospatak in Hongarye vir die bydrae en indruk wat hy op die breë kerklike terrein gemaak het. Die ontvangs van 'n ereprofessoraat in Hongarye op 14 September 2008 was 'n besondere groot hoogtepunt in sy lewe - omstandighede buite sy beheer het hom vir 'n taak na verre lande gelei, maar die uitsonderlike vader wat hy vir die Hongare in die vreemde was, is weldra begroet met die nodige dank en waardering en het vir hom weer die deur opgemaak om die land van sy vaders en sy familie in vryheid te besoek. Die sirkel van sy lewenstog is voltooi, die sirkel waarbinne hy sy taak moes vervul.

\section{Gevolgtrekking}

Die kerkhistoriese hermeneutiek van ons tyd het die negentiende eeu se flater (soos in die historiese kritisisme van teoloë soos bv. A. von Harnack) ontbloot wat kultuur sonder meer as belemmerend vir ons soeke na waarheid en werklikheid bestempel het (vgl. Young 2007:xii-xvi, 34-37). Frances Young sê byvoorbeeld van Justinus (in sy hantering van filosofiese begrippe waaraan hy nuwe inhoude gegee het vanuit die Apostoliese tradisie wat nie verlore moet gaan nie): 'Philosophy provided him and other apologists with the language and conceptual tools to explain how Jesus Christ was the revelation of the one true God' (Young 2007:35). Dit asof kultuur bloot afgewerp kon word om by 'n veronderstelde waarheid en werklikheid uit te kom. Young het uitdruklik en oortuigend die positiewe bydrae van kulturele interaksie aangetoon in die ontdekking van die noodsaaklike bydraende en vormende uitwerking daarvan om tot begrip te kom van die waarheid en die werklikheid van die verlede (vgl. Young 2007:xvi).

In die lewe van Kálmán II het die volgehoue teenwoordigheid van die een denominasie van die Hervormde Kerk vir hom 'n tuiste gebied wat hom sterk gemaak het en hom gedra het in die vreemde. En kulturele interaksie het hom gevorm en voorberei vir sy taak in die vreemde, en hom ingetrek om - as volledig deel van die nuwe bestaan - sy bydrae met oorgawe te lewer sodat hy nooit 'n buitestaander was nie. Die relevansie van hierdie verhaal vir vandag lê vir ons daarin dat ons nooit in 'n vakuum gelowige en predikant is nie. Daar is elke dag ' $n$ wêreld besig om na ons toe te kom, 'n wêreld wat vir seker iets met ons gaan maak, ons miskien in die proses selfs fyn sal maal. Maar dis nou eenmaal die wêreld waarin ons onsself bevind, en waarin ons ook geroep is om onsself te wees en ons rol te speel, 'n wêreld waarmee ons iets sinvols moet maak. Die verhaal van Kálmán II leer ons om nie te wil vlug vir die kulturele interaksie nie, want juis dit vorm jou en rus jou toe vir jou taak. Die wonderlike van hierdie verhaal is dat ons altyd tuis sal wees by die Heer en sy Kerk. 
Die verhaal van Kálmán II se lewe bevestig die hipotese dat dit kerk en kulturele interaksievormende faktore is wat 'n predikant en gelowige in staat stel om op enige plek in die wêreld die Koninkryk van die Here Jesus Christus te dien.

\section{Erkenning \\ Mededingende belange}

Die outeur verklaar dat hy geen finansiële of persoonlike verbintenis het met enige party wat hom nadelig kon beïnvloed in die skryf van hierdie artikel.

\section{Literatuurverwysings}

Bartha, T. (red), 1967, A II Helvét Hitvallás Magyarországon és Méliusz Eletmüve Magyarországi Református Egyház, Budapest. PMCid:546845

Berlitz, C., 1983, Native tongues, Granada, London.

Breytenbach, A.P.B., 1999, 'Ontwikkelings en verskuiwings in ons teologie', in D.J.C. van Wyk (red.), 20ste eeu Hervormde teologie, bl. 171-182, SENTIK, Nederduitsch Hervormde Kerk van Afrika, Pretoria.

Bucsay, M., 1977, Der Protestantismus in Ungarn 1521-1978: Ungarns Reformationskirchen in Geschichte und Gegenwart, Teil I: Im Zeitalter der Reformation, Gegenreformation und katoholischen Reform, Hermann Böhlaus, Wien/Köln/Graz.

Bucsay, M., 1979, Der Protestantismus in Ungarn 1521-1978: Ungarns Reformationskirchen in Geschichte und Gegenwart, Teil II: Vom Absolutismus bis zur Gegenwart, Hermann Böhlaus, Wien/Köln/Graz.

Haitjema, Th.L., 1926, Karl Barth, H. Veenman \& Zonen, Wageningen.

Halász, Z. (ed.), 1963, Hungary: Geography, history, political and social system, economy, living standard, culture, sports, 2nd rev. edn., Corvina, Budapest.

Hervormde Kerk van Hongarye, 1965, A Magyarországi Református Egyház Hitvallási Iratai, Magyarországi Református Egyház, Budapest.

Hervormde Kerk van Hongarye, 1997, Egyházunk: A Magyarországi Református Egyház/Our church: The Reformed Church in Hungary, Kálvin János Kiadója, Budapest.
Ignotus, P., 1972, Hungary, Ernest Benn, London.

Milotay, I., 1929, A nation sentenced to death, Magyarság, Budapest.

Nagy, B., 1967, 'A Heidelbergi Káté jelentkezése, története és kiadásai Magyarországon a XVI. és XVII. Században', in T. Bartha (red), A II Helvét Hitvallás Magyarországon és Méliusz Eletmüve, bl. 17-91, Magyarországon Református Egyház, Budapest.

Nederduitsch Hervormde Kerk van Afrika (NHKA), Argiefbewaarplek Pretoria, Argief van die Nederduitsch Hervormde Kerk: Kommissie van die Algemene Kerkvergadering 1949-1951, Notules, K 1/2 deel 1/1/8, 1949-1951.

Nederduitsch Hervormde Kerk van Afrika (NHKA,) Argiefbewaarplek Pretoria, Argie van die Nederduitsch Hervormde Kerk van Afrika (NHKA), 1951-2008, Persoonlike lêer K. Papp, K2 5/4 Dele 1, 2 \& 3.

Nederduitsch Hervormde Kerk van Afrika (NHKA), 1951, Almanak, Teologiese Fakulteit, Universiteit van Pretoria - Afdeling A, bl 137.

Pamlényi, E. (ed.), 1973, A History of Hungary, 4th edn., Corvina, Budapest.

Papp, K., 1995, 'Oorsprong van die Paardekraal-Gelofte', HTS Teologiese Studies/ Theological Studies 51(1), 189-206.

Papp, K., 1999, 'Die eerste volledige Hongaarse Bybel - ouer as die Statevertaling!', Konteks 10(10), 8-15.

Papp, K.D., 2010, 'Die lewe en werk van ds Kálmán Papp II (geb. 1924), met verwysing na die Hongaarse agtergrond, die Nederlandse periode en die Suid-Afrikaanse periode', PhD, proefskrif, Departement Kerkgeskiedenis en Kerkreg, Universiteit van Pretoria.

Papp, W., 1951-1979, Ongepubliseerde dagboek, deel I (1-340) Persoonlike argief, Krugersdorp.

Révész, I., 1956, History of the Hungarian Reformed Church, The Hungarian Reformed Federation of America, Washington.

Szabó, J.S., 1927, Der Protestantismus in Ungarn, vertl. B. von Horváth, Des Evangelischen Bundes, Berlin

Szekeres, A., 1958, s.v. 'Debrecen', in K. Galling (red.), Religion in Geschichte und Gegenwart, Bd. 2, D-G, J.C.B Mohr (Paul Siebeck), Tübingen, bl. 54.

Tóth, K. (red.), 1995, Tájékoztató a magyarországi egyházakról, A Magyarországi Egyházak Ökumenikus Tanácsa, Budapest.

Van de Beek, A., 2006, Van Kant tot Kuitert, Uitgeverij Kok, Kampen.

Van Wyk, D.J.C., 1999, 'Hervormde Kerk, teologie en lewe: Aksente en nuanses', in D.J.C. van Wyk (red.), 20ste eeu Hervormde teologie, bl. 183-198, SENTIK, Pretoria. Young, F.M ., 2007, The making of the creeds, SCM Press London.

Zsindely, E., 1967, 'Bullinger Hendrik Magyar kapcsolatai', in T. Bartha (ed.), A II Helvét Hitvallás Magyarországon és Méliusz Eletmüve, pp. 55-86, Magyarországi Református Egyház, Budapest. 